Gut, 1974, 15, 549-551

\title{
The liver in boutonneuse fever
}

\author{
J. GUARDiA, J. M. MARTÍnEZ-VÁZqueZ, A. MORAGAS, C. REY, J. VilASECA, \\ J. TORNOS, M. BELTRÁN, AND R. BACARDÍ
}

From the Department of Internal Medicine, Ciudad Sanitaria de la Seguridad Social, Barcelona, Spain

SUMmaRY Hepatic lesions were studied for the first time in 13 cases of boutonneuse fever (Mediterranean exanthematous fever). The glutamic-oxalacetic transaminases were raised in eight patients, the glutamic-pyruvic transaminases showed an increase in 10 patients, alkaline phosphatases in seven of the 10 patients investigated, and conjugate bilirubin showed moderate increases in three patients. Five patients were studied histologically; this study showed lesions of a granulomatous type, similar to those described in $Q$ fever, in three patients, fatty degeneration with marked alcoholism in another patient, and a normal liver in the last patient. Two of the three patients with granulomatous lesions showed a moderate increase in alkaline phosphatases. After this report boutonneuse fever must be included among the infectious conditions that can produce granulomas within the liver.

Boutonneuse fever (Mediterranean exanthematous fever) is a disease produced by Conori rickettsia and transmitted by the bite of the dog tick (Rhipicephalus sanguineus). It is seen in the countries of the Mediterranean basin between the months of June and September, coinciding with the biological cycle of this arthropod. Its clinical course is characterized by a febrile phase, with pain in the joints and muscles, and the appearance, between the fourth and the ninth day, of a button-like eruption with inflamed vessels on the trunk and limbs. The 'black spot', or inoculation bite of the tick, is found in $80 \%$ of cases. The clinical course is benign, and complications have not been observed since the discovery of antibiotics. In some of our patients we have found enzymatic changes indicative of hepatic involvement, which led us to make a histological study of the liver and to demonstrate focal histiocytic lesions of the infiltrating type in three patients.

\section{Patients and Methods}

We studied 13 patients affected by boutonneuse fever, all of whom were diagnosed both clinically and serologically. Agglutination against Proteus OX-2 was more than 1/160 in eight cases, and against Proteus OX-19 in two cases. Specific microagglutination for Rickettsia conorii was positive with increasing titre in the seven cases in which it was carried out. Six liver biopsies were performed in five patients. The histological sections were examined Received for publication 18 April 1974. under the optical microscope, using the following staining methods: haematoxylin-eosin, Masson's trichrome, Wilder's reticulin, Perls' haemosiderin test, and Giemsa.

\section{Results}

The results of the laboratory tests are given in the table The glutamic-oxalacetic transaminases (GOT) were slightly raised in eight of the 13 cases. The glutamic-pyruvic transaminases (GPT) were raised in 10 patients, and alkaline phosphatases in seven of the 10 patients in whom they were determined. Bilirubin showed increases of the conjugate fraction of more than $0.40 \mathrm{mg}$ in three patients, and in these patients the alkaline phosphatase was also high. There were no changes in prothrombin time nor in serum proteins in any of the patients.

Histological study showed changes compatible with the diagnosis of alcoholic fatty liver in case 6 (this patient had a history of alcoholism). In another case (no. 13) the liver was of normal appearance; and in the other three the histological picture was substantially similar in all cases. The Kupffer's cells were swollen and there was some sinusoidal cellularity. Small foci of parenchymal collapse were seen within the lobules, with 'dropout' phenomena, pyknotic nuclear remnants and infiltration by histiocytes, a few polynuclear cells and some round cells, as well as by larger granulomatous lesions of indefinite outline, formed by the same cellular elements.

Portal involvement was slight, and only in one of 


\begin{tabular}{|c|c|c|c|c|c|}
\hline $\begin{array}{l}\text { Patient } \\
\text { No. }\end{array}$ & $\begin{array}{l}\text { Total and Conjugated } \\
\text { Bilirubin }(\mathrm{mg} / 100 \mathrm{ml})\end{array}$ & $\begin{array}{l}\text { SGOT (Karmen units: } \\
\text { normal }<40 u)\end{array}$ & $\begin{array}{l}\text { SGPT (Karmen units: } \\
\text { normal }<40 u)\end{array}$ & $\begin{array}{l}\text { Alkaline Phosphatase } \\
(\mathrm{mu} / \mathrm{ml}, \text { normal }<50)\end{array}$ & Biopsy \\
\hline $\begin{array}{r}1 \\
2 \\
3 \\
4 \\
5 \\
6 \\
7 \\
8 \\
9 \\
10 \\
11 \\
12 \\
13\end{array}$ & $\begin{array}{l}\overline{0} \\
0.5 \\
0.4 \\
0.4 \\
\overline{0.7} \\
1 \cdot 3-0.8 \\
1 \cdot 05-0.6 \\
0.45 \\
0.75-0.30 \\
0.45 \\
1-0.60 \\
0.5\end{array}$ & $\begin{array}{r}38 \\
27 \\
56 \\
65 \\
128 \\
420 \\
107 \\
101 \\
49 \\
60 \\
22 \\
34 \\
34 \\
\end{array}$ & $\begin{array}{r}22 \\
25 \\
48 \\
46 \\
46 \\
280 \\
60 \\
98 \\
43 \\
46 \\
26 \\
42 \\
46\end{array}$ & $\begin{array}{l}65 \\
65 \\
85 \\
- \\
80 \\
76 \\
40 \\
80 \\
22 \\
40 \\
78\end{array}$ & $\begin{array}{l}- \\
- \\
- \\
\bar{F} \\
- \\
- \\
\overline{-} \\
\text { Granulty liver } \\
\text { Normal } \\
\text { Granuloma } \\
\text { Granuloma }\end{array}$ \\
\hline
\end{tabular}

Table Laboratory findings

the cases were small granulomas apparent. No giant cells were seen in any of the cases, nor had any well organized granulomas with epithelioid cells been formed. There were no acidophil bodies nor any ballooning of the cells. In two cases the Giemsa stain showed that the granulomas contained perceptible minute corpuscles, which were difficult to interpret due to the presence of abundant pigmented material which could be stained in the cytoplasma of the neighbouring hepatocytes. There was slight fatty degeneration in only one of the biopsies and very slight fatty degeneration in another case (figs $1,2,3$ ).

\section{Discussion}

In the original descriptions of boutonneuse fever the complication considered to be the most important was the involvement of the central nervous system (Pedro-Pons, 1945), and more recently the existence of pneumonitis (Lemenager, Morel, Bernard, and

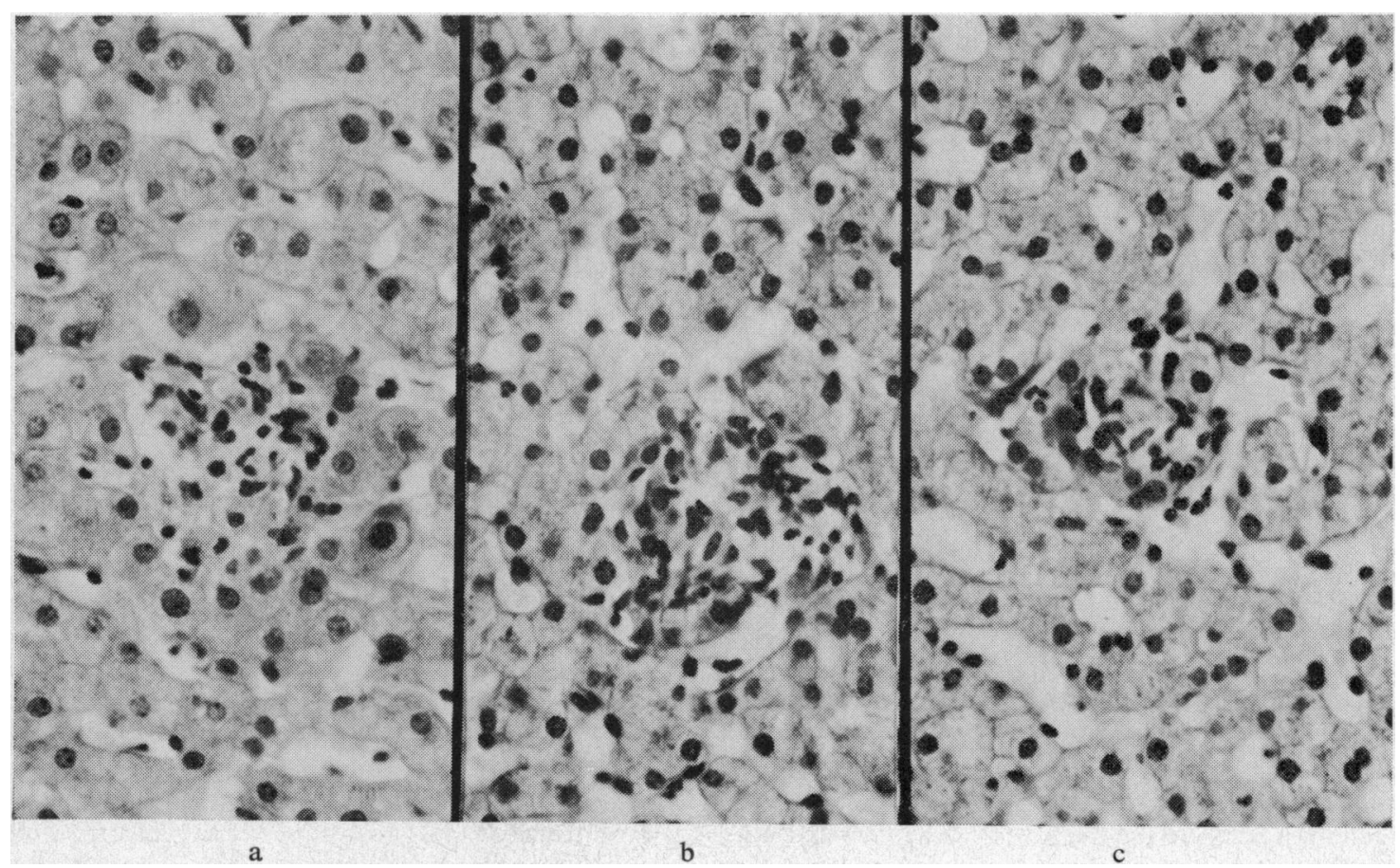

Fig 1 a, b, c Small intralobular granulomatous foci, with slight 'dropout'phenomena and infiltration with histiocytes, a few polynuclear cells, and an occasional round cell $(H E \times 250)$ 


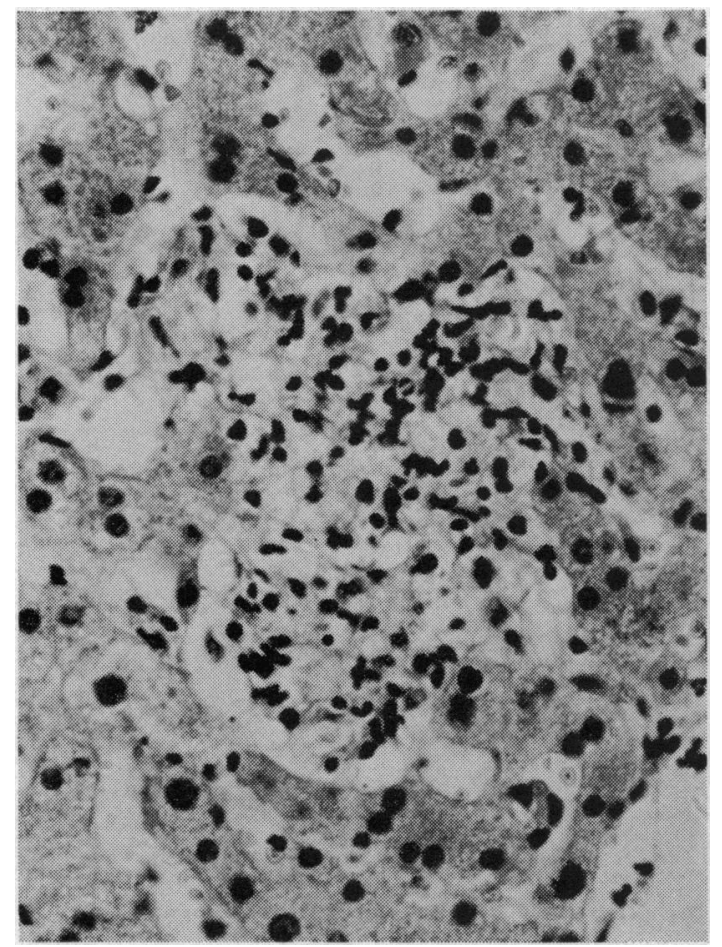

Fig 2

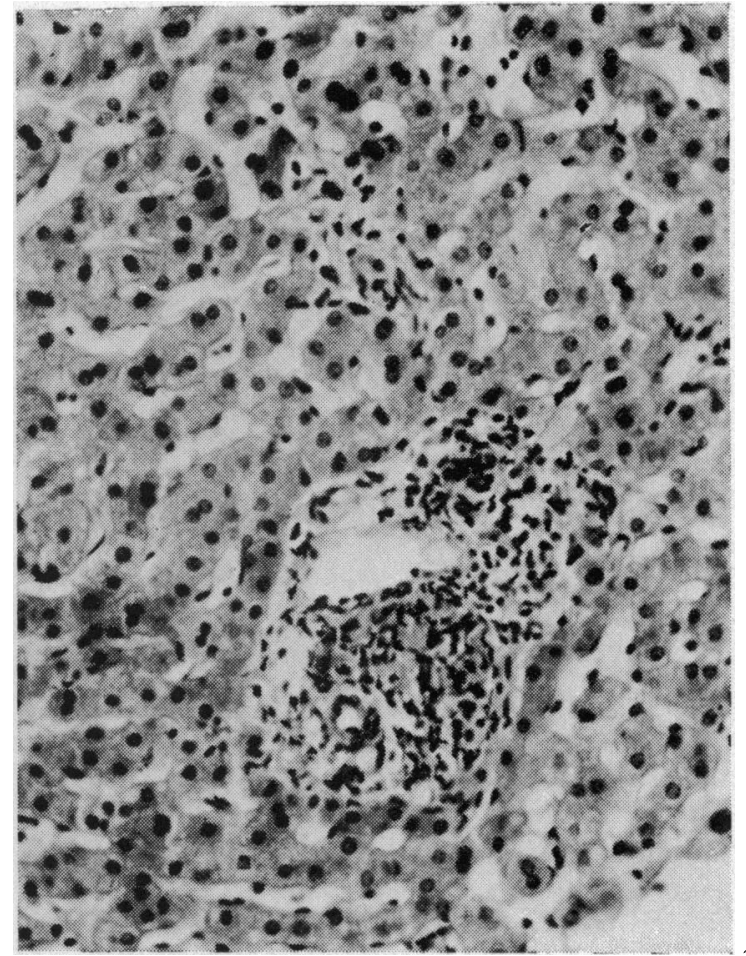

Fig 3

Fig 2 Nodular granulomatous area, poorly defined, with collapse of the parenchyma and infiltration of histiocytes together with polynuclear cells and round cells. No epithelioid transformation $(\mathrm{HE} \times 200)$.

Fig 3 Granulomas in a portal space, with a very small incipient lesion within a neighbouring lobule $(H E \times 125)$.

Freymuth, 1972) and of arteritis (Giroud, 1957) has been stressed. The hepatic lesions that we found in three of our cases may be described as focal infiltrating hepatitis with a tendency to the formation of granulomas. Morphologically these are similar to those described in $\mathbf{Q}$ fever (Picchi, Nelson, Waller, Razavi, and Clizer, 1960; Bernstein, Edmondson, and Barbour, 1965; Dupont, Hornick, Levin, Rapoport, and Woodward, 1971). We have found no description of hepatic lesions in other forms of rickettsiosis although in isolated cases of Rocky Mountain spotted fever increased transaminases have been described (Hand, Miller, Reinarz, and Sanford, 1970), although these patients were not studied histologically.

In our patients the hepatic changes in boutonneuse fever led to no clinical repercussions. The enzymatic increases were very moderate and transitory. In two of the three cases in which granulomatous types of lesion existed, the alkaline phosphatases were increased but the transaminases were nearly normal. Although no assertions can be made con- cerning the mechanism that causes the lesions, since it is not certain that the infective agent is present within the granuloma, boutonneuse fever must henceforth be included among the infectious conditions that are capable of producing a granulomatous type of lesion in the liver.

\section{References}

Bernstein, M., Edmondson, H. A., and Barbour, B. H. (1965). The liver lesion in $\mathrm{Q}$ fever. Arch. intern. Med., 116, 491-498.

Dupont, H. L., Hornick, R. B., Levin, H. S., Rapoport, M. I., and Woodward, T. E. (1971). Q fever hepatitis. Ann. intern. Med., 74, 198-206.

Giroud, P. (1957). Réactions biologiques, test spécifiques permettant le diagnostic des atteintes vasculaires dues a des rickettsies ou à des éléments à leur limite (néorickettsies). Presse méd., 65, 1019.

Hand, W. L., Miller, J. B., Reinarz, J. A., and Sanford, J. P. (1970) Rocky Mountain spotted fever: a vascular disease. Arch. ternin. Med., 125, 879-882.

Lemenager, J., Morel, C., Benard, Y., and Freymuth, F. (1972). Rickettsioses pleuro-pulmonaires (Letter). Nouv. Presse méd. $1,2622$.

Pedro-Pons, A. (1945). Fiebre exantemática mediterránea. Med. clin. (Barcelona), 5, 1-6.

Picchi, J., Nelson, A. R., Waller, E. E., Razavi, M., and Clizer, M. D. (1960). $Q$ fever associated with granulomatous hepatitis. Ann. intern. Med., 53, 1065-1074. 